\title{
Identification of Potential Probiotics Producing Bacteriocins Active against Listeria monocytogenes by a Combination of Screening Tools
}

\author{
Christian K. Desiderato ${ }^{1}$, Steffen Sachsenmaier ${ }^{1}$, Kirill V. Ovchinnikov ${ }^{2}$, Jonas Stohr ${ }^{1}$, Susanne Jacksch ${ }^{3}{ }^{1}$, \\ Dominique N. Desef ${ }^{1}$, Peter Crauwels ${ }^{1}$, Markus Egert ${ }^{3}{ }^{\circledR}$, Dzung B. Diep ${ }^{2}$, Oliver Goldbeck ${ }^{1}$ \\ and Christian U. Riedel ${ }^{1, *}$ (D) \\ 1 Institute of Microbiology and Biotechnology, University of Ulm, Albert-Einstein-Allee 11, \\ 89081 Ulm, Germany; christian.desiderato@uni-ulm.de (C.K.D.); federer.sachsenmaier@gmail.com (S.S.); \\ jonas.stohr@web.de (J.S.); dominique.desef@uni-ulm.de (D.N.D.); petcrauwels@hotmail.com (P.C.); \\ oliver.goldbeck@uni-ulm.de (O.G.) \\ 2 Faculty of Chemistry, Biotechnology and Food Science, Norwegian University of Life Sciences, \\ Universitetstunet 3, 1433 Ås, Norway; kirill.ovchinnikov@nmbu.no (K.V.O.); dzung.diep@nmbu.no (D.B.D.) \\ 3 Faculty of Medical and Life Sciences, Institute of Precision Medicine, Furtwangen University, \\ Campus Schwenningen, Jakob-Kienzle-Straße 17, 78054 Villingen-Schwenningen, Germany; \\ Susanne.Jacksch@hs-furtwangen.de (S.J.); Markus.Egert@hs-furtwangen.de (M.E.) \\ * Correspondence: christian.riedel@uni-ulm.de; Tel.: +49-731-5024853
}

Citation: Desiderato, C.K.; Sachsenmaier, S.; Ovchinnikov, K.V.; Stohr, J.; Jacksch, S.; Desef, D.N.; Crauwels, P.; Egert, M.; Diep, D.B.; Goldbeck, O.; et al. Identification of Potential Probiotics Producing Bacteriocins Active against Listeria monocytogenes by a Combination of Screening Tools. Int. J. Mol. Sci. 2021, 22, 8615. https://doi.org/10.3390/ ijms22168615

Academic Editor: Andreas Schwiertz

Received: 27 July 2021

Accepted: 9 August 2021

Published: 10 August 2021

Publisher's Note: MDPI stays neutral with regard to jurisdictional claims in published maps and institutional affiliations.

Copyright: (c) 2021 by the authors. Licensee MDPI, Basel, Switzerland. This article is an open access article distributed under the terms and conditions of the Creative Commons Attribution (CC BY) license (https:// creativecommons.org/licenses/by/ $4.0 /)$.
Abstract: Listeria monocytogenes is an important food-borne pathogen and a serious concern to food industries. Bacteriocins are antimicrobial peptides produced naturally by a wide range of bacteria mostly belonging to the group of lactic acid bacteria (LAB), which also comprises many strains used as starter cultures or probiotic supplements. Consequently, multifunctional strains that produce bacteriocins are an attractive approach to combine a green-label approach for food preservation with an important probiotic trait. Here, a collection of bacterial isolates from raw cow's milk was typed by $16 S$ rRNA gene sequencing and MALDI-Biotyping and supernatants were screened for the production of antimicrobial compounds. Screening was performed with live Listeria monocytogenes biosensors using a growth-dependent assay and pHluorin, a pH-dependent protein reporting membrane damage. Purification by cation exchange chromatography and further investigation of the active compounds in supernatants of two isolates belonging to the species Pediococcus acidilactici and Lactococcus garvieae suggest that their antimicrobial activity is related to heat-stable proteins/peptides that presumably belong to the class IIa bacteriocins. In conclusion, we present a pipeline of methods for high-throughput screening of strain libraries for potential starter cultures and probiotics producing antimicrobial compounds and their identification and analysis.

Keywords: Listeria monocytogenes; food; control; antimicrobial peptide; bacteriocin; lactic acid bacteria

\section{Introduction}

Listeria monocytogenes is a saprophytic soil bacterium and an important intracellular pathogen of humans and animals [1]. Due to its versatile lifestyle and ability to grow under a wide range of stressful conditions, L. monocytogenes is highly competitive in the environment, under conditions of food production and preservation, in different food matrices and the gastrointestinal tract of the host [2,3]. Listeriosis (i.e., the disease caused by L. monocytogenes) is usually acquired upon consumption of contaminated food products. In otherwise healthy individuals, the course of the disease is relatively mild or even asymptomatic. However, in high-risk groups (e.g., pregnant women, newborns, elderly people, immunosuppressed patients, etc.), the disease may be very severe and even fatal [4]. A clear and steady increase in the number of cases of listeriosis has been observed in recent years [5]. In 2014, there were 2206 confirmed cases of listeriosis in humans in the European 
Union, with a mortality rate of approximately $18 \%$ [5]. This makes listeriosis by far the deadliest food-borne disease in humans.

One of the reasons for the rising numbers of listeriosis outbreaks is an increased demand of consumers for ready-to-eat and minimally processed foods, which are particularly vulnerable to contaminations with foodborne pathogens. At the same time, reduced shelf life of such products leads to an increase in production costs, prices for consumers, and the amount of food waste. Therefore, the development of new methods for cost-effective and efficient preservation that, at the same time, maintain taste, texture, sensory, and nutritional properties, are of considerable interest. A green-label approach for food preservation that meets most of these criteria are antimicrobial peptides (AMPs) termed bacteriocins [6-8]. Additionally, bacteriocin-producing bacteria have been shown to protect against infections with pathogenic microorganisms [9-13] and is thus considered an important criterion for the selection of probiotic bacteria [14,15].

Bacteriocins are ribosomally synthesized antimicrobial peptides naturally produced by a wide range of bacteria, especially of lactic acid bacteria (LAB), and released into the extracellular environment $[16,17]$. They are able to suppress growth or directly kill target organisms in a specific manner and their biological role is to provide a competitive advantage of the producing organisms in an ecological niche [17]. Based on size, presence of (extensive) posttranslational modifications, and thermostability bacteriocins are categorized into three main classes with various subclasses $[8,18]$. Class I and II bacteriocins are small $(<10 \mathrm{kDa})$, heat-stable peptides that differ in the extent of their post-translational modification. Class I bacteriocins are modified by dedicated enzymatic modification machineries resulting in unusual amino acid residues. Similar modifications are absent in class II bacteriocins. They may, however, be translated as (inactive) pre-peptides, activated upon transport by cleavage of the leader peptides and contain stabilizing disulfide bonds. In contrast, class III contains large, heat-labile antimicrobial peptides.

Most bacteriocins are active against organisms closely related to the producer, which are immune against their own bacteriocin. Nevertheless, some bacteriocins have a broader spectrum of target organisms [16]. Depending on the mechanism, bacteriocins are either bacteriostatic and/or bactericidal for their targets. For nisin and other class I bacteriocins, it has been shown that their activity is mediated via lipid II $[19,20]$, which is an essential carrier molecule for cell wall precursors. The bacteriostatic activity is achieved by the binding of nisin to lipid II. This inhibits cell wall synthesis and thus growth of target organisms, even at lower concentrations. At higher concentrations, lipid II and nisin form pore complexes in the cytoplasmic membrane, leading to membrane depolarization and killing of the target. Pore formation has also been described as the mechanism of action of class II bacteriocins. There are several receptors described for different class II bacteriocins including mannose phosphotransferase systems (PTS ${ }^{\mathrm{Man}}$ ) [21-24] and maltose ATP-binding cassette transporter [25]. However, the exact mechanisms or pore formation of these class II bacteriocins is largely unknown. It is currently under debate if the pores are formed exclusively by the peptides after receptor binding or if pores are formed in complex with other molecules.

For food preservation, bacteriocins can either be produced ex situ and added during or after production. Alternatively, bacteriocin-producing bacteria may be added during or after production as protective cultures or probiotic supplements [26]. Despite their advantageous properties, merely a handful of bacteriocins are currently approved and marketed for use in food $[17,26]$. This highlights the need for rapid, reliable, and costefficient methods for the identification and characterization of novel bacteriocins and their producers. Ideally, the screening methods already provide information on the potential mechanisms. In most studies, bacteriocin-producing bacteria are identified by classical plating methods and measurements of inhibition zones of an indicator organism around a colony of the producer [27]. Alternatively, there are a number of bioinformatic tools for in silico prediction of bacteriocin gene clusters in genomic and metagenomic datasets [28-30]. 
We recently generated L. monocytogenes biosensors expressing the ratiometric $\mathrm{pH}-$ sensitive fluorescent protein pHluorin that allow for easy monitoring of membranedamaging activity of bacteriocins [31]. The pHluorin protein has a bimodal excitation spectrum [32] and relative fluorescence intensity at the two excitation peaks shifts in response to changes in $\mathrm{pH}$ in a ratiometric manner [32]. Under steady-state conditions, L. monocytogenes possesses an intracellular $\mathrm{pH}\left(\mathrm{pH}_{\mathrm{i}}\right)$ of 7.6-8.0 [33]. However, when placed in a buffer with acidic $\mathrm{pH}$ and exposed to compounds that disrupt membrane integrity, the internal $\mathrm{pH}_{\mathrm{i}}$ will rapidly change to the extracellular $\mathrm{pH}$ of the buffer, and this shift can be detected by the changes in the relative intensity of fluorescence after excitation at 400 and $470 \mathrm{~nm}$. Thus, in an acidic buffer system, the L. monocytogenes biosensor can be used to detect compounds with membrane damaging activity [31].

Here, these biosensors were used to screen supernatants of a library of bacterial isolates from raw cow's milk for growth inhibition and membrane damaging activity. This allowed for the identification of probiotic candidates that produce antimicrobial compounds. The antimicrobial compounds were further purified and characterized.

\section{Results}

\subsection{Isolation and Typing of LAB from Raw Cow Milk}

The collection of 55 raw milk isolates was typed by $16 \mathrm{~S}$ rRNA gene sequencing and MALDI-Biotyping (Supplementary Table S1). According to $16 \mathrm{~S}$ rRNA gene sequences, all isolates were identified to the species level and belong to genera of the lactic acid bacteria except for isolates 14 and 16, which were typed as Corynebacterium glutamicum. The results obtained by MALDI-Biotyping were mostly in agreement with the $16 \mathrm{~S}$ rRNA gene sequences, but generally less accurate. For 13 isolates, no identification was achieved by MALDI-Biotyping as no matching spectrum was found in the database. For one isolate, identification was only possible on the genus level and for isolates 7, 10, 22, 24, 34, 35, 39,50 , and 56, the results of the MALDI-Biotyping contradicted identification based on $16 \mathrm{~S}$ rRNA gene sequences. The positive control, P. acidilactici 347 , was typed as P. lolii or Pediococcus spp. by $16 \mathrm{~S}$ rRNA gene sequencing and MALDI typing, respectively. According to the List of Prokaryotic Names with Standing in Nomenclature of the German Collection of Microorganisms and Cell Cultures, P. lolii is synonymous with P. acidilactici [34]. Thus, all isolates identified as $P$. lolii were termed P. acidilactici in this study. Isolate 34 was typed as $L$. garvieae, according to the MALDI-TOF results as its $16 \mathrm{~S}$ rRNA gene sequence had the same identity to the NCBI database sequences for L. petauri and L. garvieae. In total, bacteria of six different genera and 10 different species were identified and the most prevalent species isolated were L. lactis (14 isolates) and L. garvieae (13 isolates).

\subsection{Screening of Supernatants for Antimicrobial Activity}

All isolates were grown on MRS medium, and supernatants were collected and screened for antimicrobial activity using L. monocytogenes EGD-e/pNZ-P $\mathrm{P}_{\text {help }}$-pHluorin [31] as a sensor in two different assays (Figure 1). Supernatants of 27 isolates (i.e., $49 \%$ ) were able to inhibit growth of the sensor strain significantly compared to supernatants of L. lactis MG1363 (i.e., a strain that does not produce a bacteriocin). However, the levels of inhibition varied greatly between isolates. Complete inhibition of growth of the sensor strain was only observed for six isolates (11\%) and the pediocin-producing control strain P. acidilactici 347.

Similar results were obtained using the ratiometric $\mathrm{pH}$-dependent fluorescence of pHluorin as a read out for membrane damage. Here, the number of supernatants that produced an effect on membrane integrity was markedly lower. Of the 55 tested supernatants, only nine (i.e., $16 \%$ ) significantly reduced the fluorescence ratio of pHluorin compared to the supernatant of the non-producer L. lactis MG1363 (Figure 1B). Interestingly, those were also the top nine strains that showed the most efficient growth inhibition. These top nine isolates belong to the species P. acidilactici (isolates M1, M3, 13, and 27), E. faecium (isolates M4 and M9), L. lactis (isolates M7 and 18), and L. garvieae (isolate 17) all of which contain natural producers of a variety of bacteriocins [18]. 
(a)
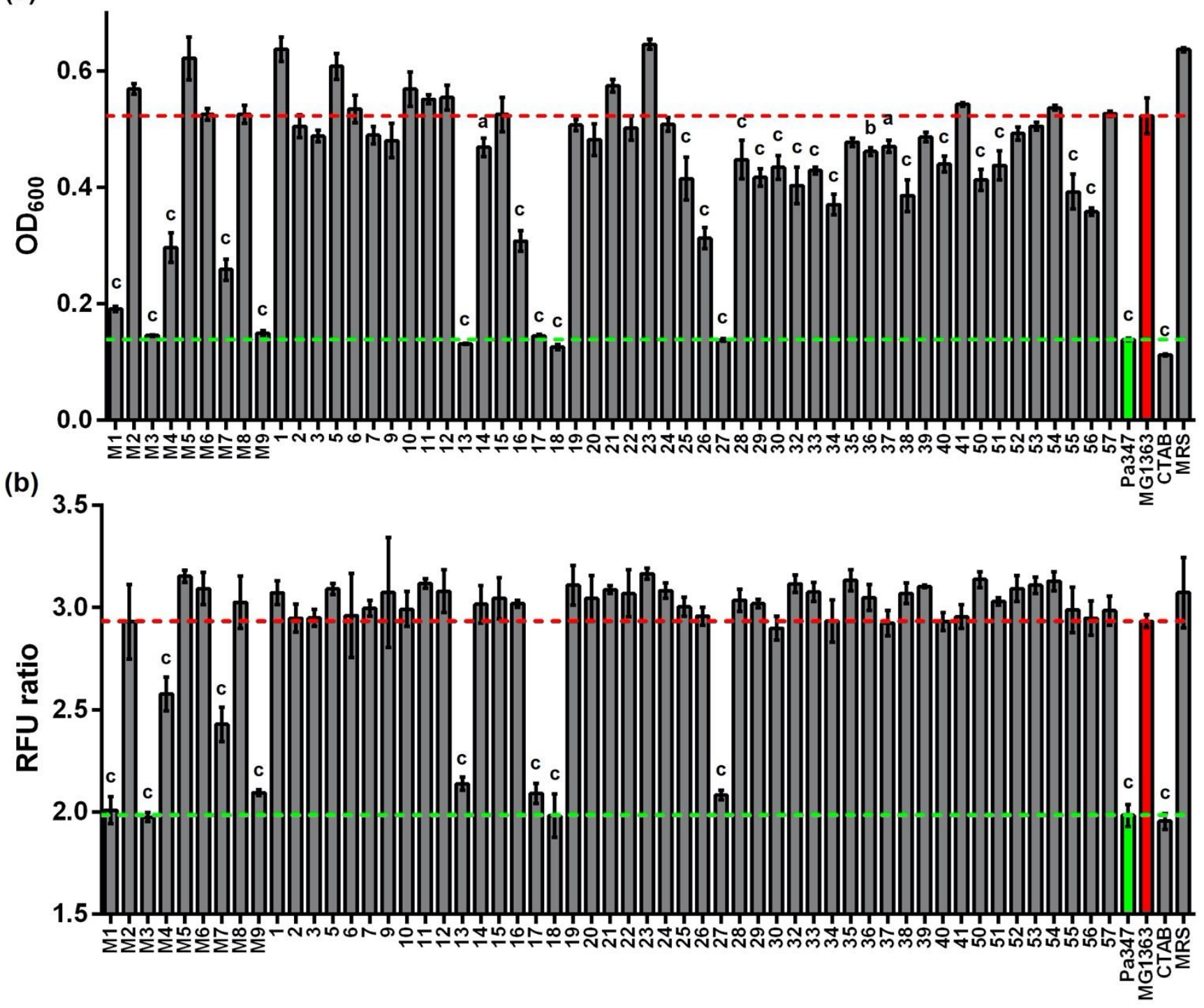

Figure 1. (a) Growth inhibitory and (b) membrane damaging activity in supernatants of LAB isolated from raw cow's milk. LAB isolates were grown in $5 \mathrm{~mL}$ MRS medium in glass tubes. Activity was measured in culture supernatants after o/N growth using L. monocytogenes EGDe/pNZ- $\mathrm{P}_{\text {help }}$-pHluorin as an indicator. Values are $\mathrm{OD}_{600}$ of the indicator strain (a) or ratio of fluorescence intensity (RFU ratio; emission at $510 \mathrm{~nm}, \mathrm{~b}$ ) after excitation at 400 and $470 \mathrm{~nm}$ and are mean \pm standard deviation (SD) of $n=3$ independent experiments. Supernatants of the pediocin producer P. acidilactici 347 (Pa347) and the non-bacteriocin producer L. lactis MG1363 were used as biological controls. The broken red and green lines indicate $\mathrm{OD}_{600}$ of the positive (i.e., complete inhibition of growth by CTAB) or negative (i.e., sterile MRS medium) controls), respectively. Statistical analysis was performed using one-way ANOVA with the Bonferroni post-test to calculate $p$-values adjusted for multiple comparisons and values obtained with supernatants of the non-bacteriocin producer L. lactis MG1363 set as the control condition (a: $p<0.05 ; \mathrm{b}: p<0.01$; $\mathrm{c} p<0.001$ ).

\subsection{Characterization of the Antimicrobial Activity of Representative Isolates}

To confirm the results of the screening, antimicrobial activity was estimated by growth inhibition assays with serial dilutions of the supernatants of $\mathrm{o} / \mathrm{N}$ cultures of two representative isolates of the species P. acidilactici and L. garvieae. Supernatants of P. acidilactici M1 and L. garvieae 17 contained high levels of antimicrobial activity comparable or only marginally lower than those observed for P. acidilactici 347 (Figure 2). Further experiments were performed to investigate the kinetics of production of the antimicrobial compound by the two isolates M1 and 17 in comparison to the control strain P. acidilactici 347. 


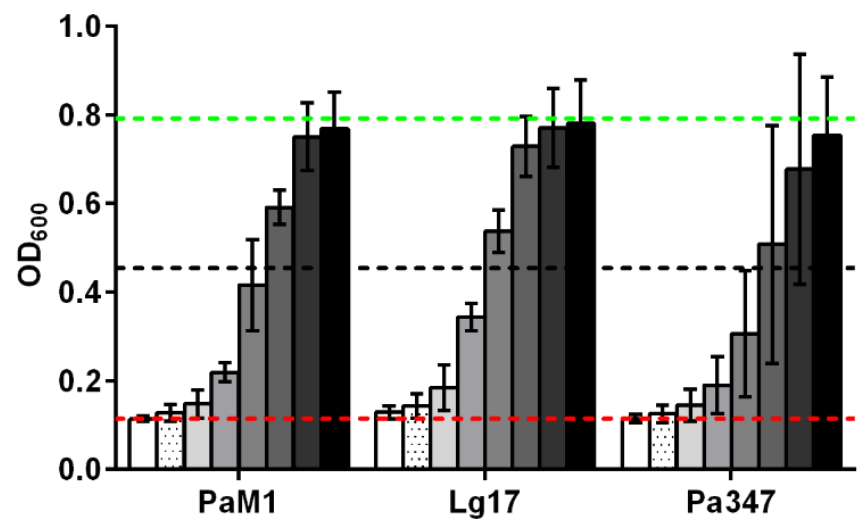

\begin{tabular}{c|c} 
Strain & Activity $[\mathrm{BU} / \mathrm{mL}]$ \\
\hline PaM1 & 2560 \\
\hline Lg17 & 1280 \\
\hline Pa347 & 2560
\end{tabular}

Figure 2. Inhibition of growth of L. monocytogenes EGDe/pNZ-P help-pHluorin by 2-fold serial dilutions (1:8-1:1024, indicated by a white-black scale) of supernatants of LAB isolates P. acidilactici M1 (PaM1), E. faecium M4 (EfM4), L. garvieae 17 (Lg17), and L. lactis 18 (L118) or P. acidilactici 347 (Pa347). Bacteria were grown o/ $\mathrm{N}$ in $5 \mathrm{~mL}$ MRS medium in glass tubes. Values are $\mathrm{OD}_{600}$ of the indicator strain $\pm \mathrm{SD}$ of $n=4$ independent experiments. The broken red and green lines indicate $\mathrm{OD}_{600} \mathrm{of} \mathrm{the}$ positive (i.e., complete inhibition of growth) or negative (i.e., sterile MRS medium) controls, respectively. The broken black lines represent growth inhibition of $50 \%$ (i.e., the threshold to calculate bacteriocin units).

All three strains showed distinct profiles of optical density $\left(\mathrm{OD}_{600}\right), \mathrm{pH}$, and antimicrobial activity when cultured in MRS broth (Figure 3). Growth and $\mathrm{pH}$ of the two P. acidilactici strains M1 and 347 were clearly different with P. acidilactici M1 showing considerably slower growth and lower final $\mathrm{OD}_{600}$ (Figure 3a). This was also reflected by faster and more pronounced acidification of spent culture medium by P. acidilactici 347. L. garvieae 17 reached similar final $\mathrm{OD}_{600}$ as $P$. acidilactici 347 , but showed somewhat slower growth in late exponential growth phase and acidification of the culture broth was not as pronounced.

(a)

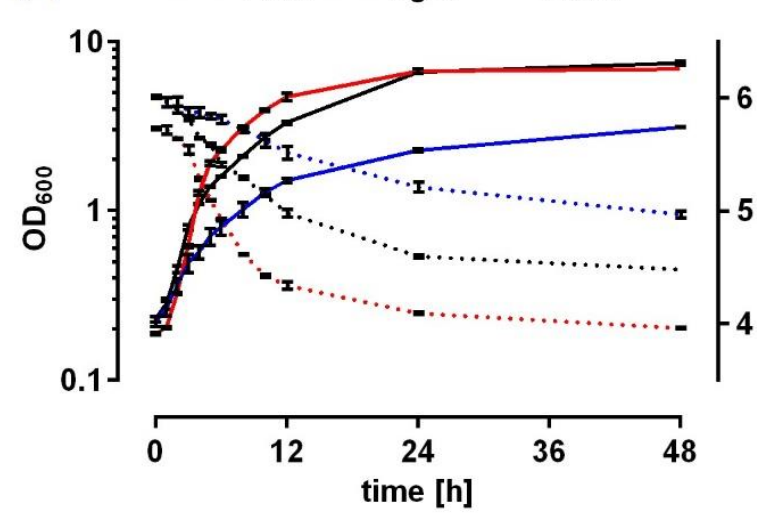

(b)

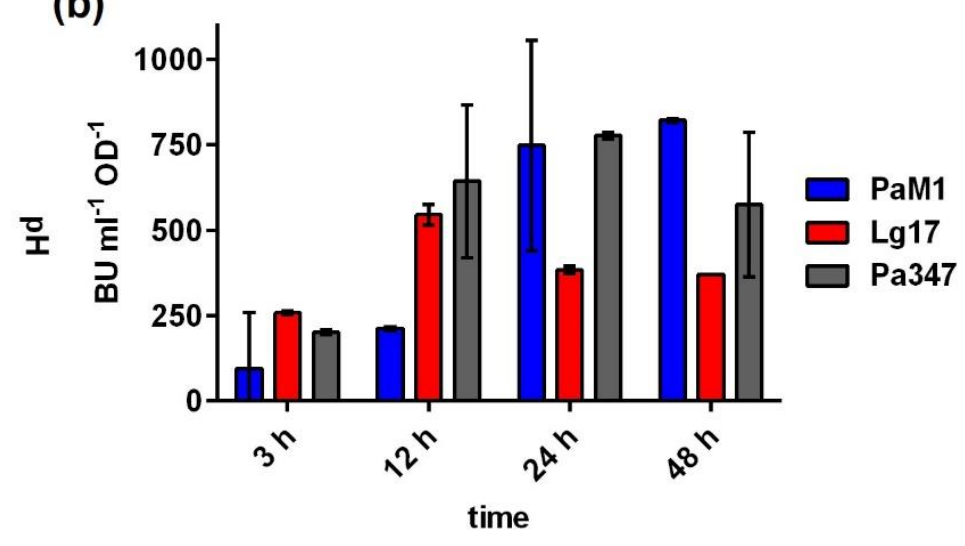

Figure 3. (a) Growth ( $\mathrm{OD}_{600}$; solid lines) and $\mathrm{pH}$ (dotted lines) cultures of P. acidiclactici $\mathrm{M} 1$ (blue), L. garvieae 17 (red), or P. acidilactici 347 (black) grown in MRS medium. (b) Relative antimicrobial activity (BU ml ${ }^{-1} \mathrm{OD}^{-1}$ ) in supernatants of the cultivations shown in (a) collected at the indicated time points. BU ml ${ }^{-1}$ were calculated based on the highest dilution showing at least $50 \%$ of growth inhibition of the sensor strain (L. monocytogenes EGDe/pNZ-P help-pHluorin) and were normalized to the $\mathrm{OD}_{600}$ of the culture at the respective timepoint. All values are mean \pm standard deviation of $n=3$ independent cultivation.

In line with a more rapid growth, OD-normalized antimicrobial activity increased more rapidly in culture supernatants of $P$. acidilactici 347 compared to $P$. acidilactici M1 (Figure 3b), but both strains reached comparable levels (approx. $750-780 \mathrm{BU} \mathrm{ml}^{-1} \mathrm{OD}^{-1}$ ) after $24 \mathrm{~h}$. The kinetics of production of the antimicrobial activity by L. garvieae 17 was clearly distinct from the P. acidilactici strains. Similar to P. acidilactici 347 , antimicrobial activity increased during exponential growth until $12 \mathrm{~h}(2560 \mathrm{BU} / \mathrm{mL}$, data not shown) and 
remained constant thereafter. However, $\mathrm{OD}_{600}$ still increased from approx. 5 to 7 between $\mathrm{t}=12$ and $24 \mathrm{~h}$, resulting in reduced OD-normalized activity (Figure $3 \mathrm{~b}$ ).

\subsection{Partial Purification and Characterization of the Antimicrobial Compounds of P. Acidilacici M1 and L. Garvieae 17}

For purification and characterization of the antimicrobial compounds produced by P. acidilactici M1 and L. garvieae 17, supernatant proteins were precipitated and further purified via cation exchange chromatography. Similar to samples of the control strain P. acidilactici 347 , elution profiles of supernatant proteins of the two isolates contained a prominent peak in absorbance at $214 \mathrm{~nm}$ at the onset of elution (Figure 4a). Peak fractions were collected and further analyzed.
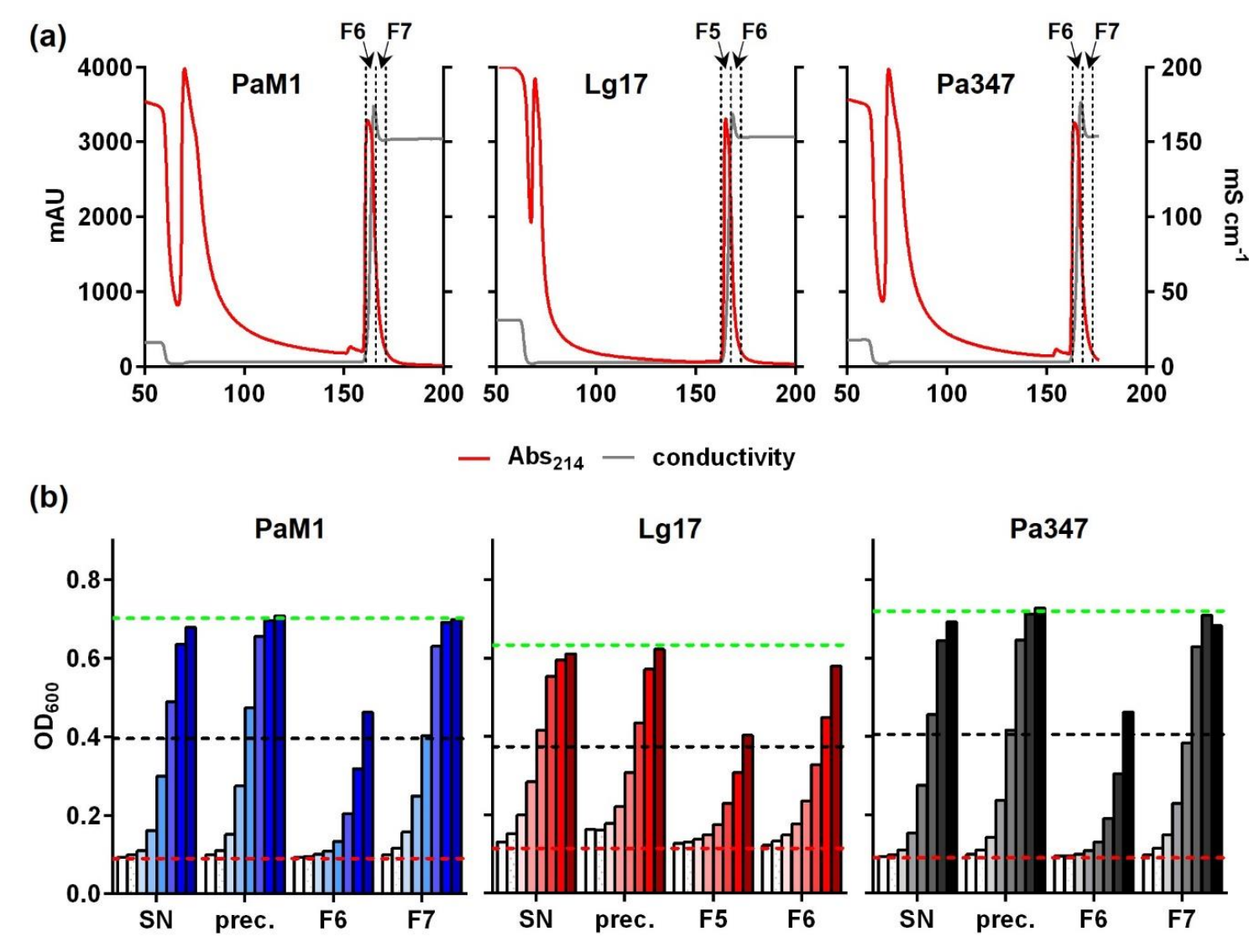

Figure 4. (a) Cation exchange chromatography of ammonium sulfate precipitated supernatant proteins of $P$. acidilactici M1 (PaM1), L. garvieae 17 (Lg17), and P. acidilactici 347 (Pa347) following growth in MRS medium. Red lines indicate absorbance at $214 \mathrm{~nm}$ in milli arbitrary units (mAU) and grey lines the conductivity in $\mathrm{mS} / \mathrm{cm}$. Broken vertical lines indicate the boundaries of fractions F6 and F7 of the eluate collected for further analysis. (b) Inhibition of growth of L. monocytogenes EGDe/pNZ-P ${ }_{\text {help }}$-pHluorin by 2-fold serial dilutions of different steps of the purification of antimicrobial compounds of P. acidilactici M1 (PaM1), L. garvieae 17 (Lg17), and P. acidilactici 347 (Pa347). SN: spent culture supernatants; prec: ammonium sulfate-precipitated supernatant proteins; F5, F6, F7: fractions 5, 6, or 7 of the elution step of cation exchange chromatography of precipitated supernatant proteins shown in (a). Dilutions were 1:16-1:2048 and are indicated by a color scale with increasing intensity. Values are $\mathrm{OD}_{600}$ of the indicator strain and are mean \pm standard deviation of duplicate measurements of one representative preparation for each strain. The broken red and green lines indicate $\mathrm{OD}_{600}$ of the positive (i.e., complete inhibition of growth) or negative (i.e., sterile MRS medium) controls, respectively. The broken black lines represent growth inhibition of $50 \%$ (i.e., the threshold to calculate bacteriocin units).

Antimicrobial activity was assayed in samples of different steps during the purification process. For all strains, peak fractions of the CIEX chromatography strongly inhibited

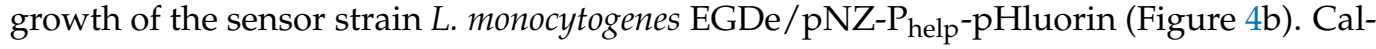


culations of $\mathrm{BU} / \mathrm{mL}$ total activity in each sample and recovery rates relative to the initial activity in untreated supernatants (Table 1 ) revealed that only about $5 \%$ of the total activity was recovered from supernatants of $P$. acidilactici $\mathrm{M} 1$ by ammonium sulfate precipitation. Subsequent CIEX chromatography was efficient and about $4.5 \%$ of the initial activity was contained in combined fractions 6 and 7. Recovery of the activity was slightly higher $(20 \%$ after precipitation and 12\% in combined CIEX fractions F5 and F6) for L. garvieae 17.

Table 1. Antimicrobial activity in samples of different steps of the purification of antimicrobial compounds of $P$. acidilactici M1 (PaM1), L. garvieae 17 (Lg17), or P. acidilactici 347 (Pa347). SN: spent culture supernatants; prec.: ammonium sulfateprecipitated supernatant proteins; F6, F7: fractions 6 and 7 of the elution step of cation exchange chromatography of precipitated supernatant proteins shown in Figure 4. Activity was calculated as BU/mL based on the highest dilution showing at least $50 \%$ of growth inhibition in the experiment shown in Figure 4 . Total activity in each sample (total BU) was calculated using the BU/mL values and the total volume of each sample. Additionally, the recovery in \% of the total activity of the entire supernatant of each culture is provided.

\begin{tabular}{|c|c|c|c|c|c|c|c|}
\hline \multirow[b]{2}{*}{ Sample } & \multirow[b]{2}{*}{$\begin{array}{c}\text { Volume } \\
\text { [mL] }\end{array}$} & \multicolumn{2}{|c|}{ PaM1 } & \multicolumn{2}{|c|}{ Lg17 } & \multicolumn{2}{|c|}{ Рa347 } \\
\hline & & $\mathrm{BU} / \mathrm{mL}$ & $\begin{array}{c}\text { Total BU } \\
\text { (Recovery) }\end{array}$ & $\mathrm{BU} / \mathrm{mL}$ & $\begin{array}{c}\text { Total BU } \\
\text { (Recovery) }\end{array}$ & $\mathrm{BU} / \mathrm{mL}$ & $\begin{array}{l}\text { Total BU } \\
\text { (Recovery) }\end{array}$ \\
\hline $\mathrm{SN}$ & 500 & 5120 & $\begin{array}{c}2,560,000 \\
(100 \%)\end{array}$ & 2560 & $\begin{array}{c}1,280,000 \\
(100 \%)\end{array}$ & 5120 & $\begin{array}{c}2,560,000 \\
(100 \%)\end{array}$ \\
\hline Prec. & 50 & 2560 & $128,000(5 \%)$ & 2560 & $256,000(20 \%)$ & 2560 & $128,000(5 \%)$ \\
\hline $\mathrm{F} 6^{\mathrm{a}}$ & 5 & 20,480 & $102,400(4 \%)$ & 20,480 & $102,400(8 \%)$ & 20,480 & $102,400(4 \%)$ \\
\hline $\mathrm{F}^{\mathrm{a}}$ & 5 & 2560 & $12,800(0.5 \%)$ & 2560 & $51,200(4 \%)$ & 5120 & $12,800(0.5 \%)$ \\
\hline
\end{tabular}

${ }^{\text {a: }}$ For Lg17, CIEX fractions 5 and 6 were used as indicated in Figure 4a.

Similar to samples of the positive control strain P. acidilactici 347, antimicrobial activity of both isolates was efficiently abolished by treatment with proteinase $\mathrm{K}$, but was resistant to heat treatment (Figure 5a). This indicated that the antimicrobial compounds in the supernatants of P. acidilactici M1 and L. garvieae 17 are heat-stable peptides, potentially bacteriocins.

The species P. acidilactici and L. garvieae are known to contain strains that produce different class IIa bacteriocins $[35,36]$. Bacteriocins of this class are known to require PTSMan subunits IIC and IID as receptors to exert their activity. To test if the antimicrobial peptides of isolates M1 and 17 also act in a PTS ${ }^{\text {Man }}$-dependent manner, we tested their activity in a spot-on-lawn assay using L. monocytogenes EGDe or EGY2 (i.e., an isogenic mutant carrying a 84 bp deletion in the mptD gene encoding the IID subunits of the PTS ${ }^{\text {Man }}$ that was shown to be resistant to the class Ila bacteriocin mesentericin Y105) [37]. This revealed that wildtype L. monocytogenes EGDe is highly sensitive to supernatants as well as CIEXpurified supernatant proteins of both P. acidilactici strains and L. garvieae 17 (Figure 5b). In contrast, no inhibition was observed with any of the samples when the mptD mutant strain EGY2 was used as the sensor. 
(a)

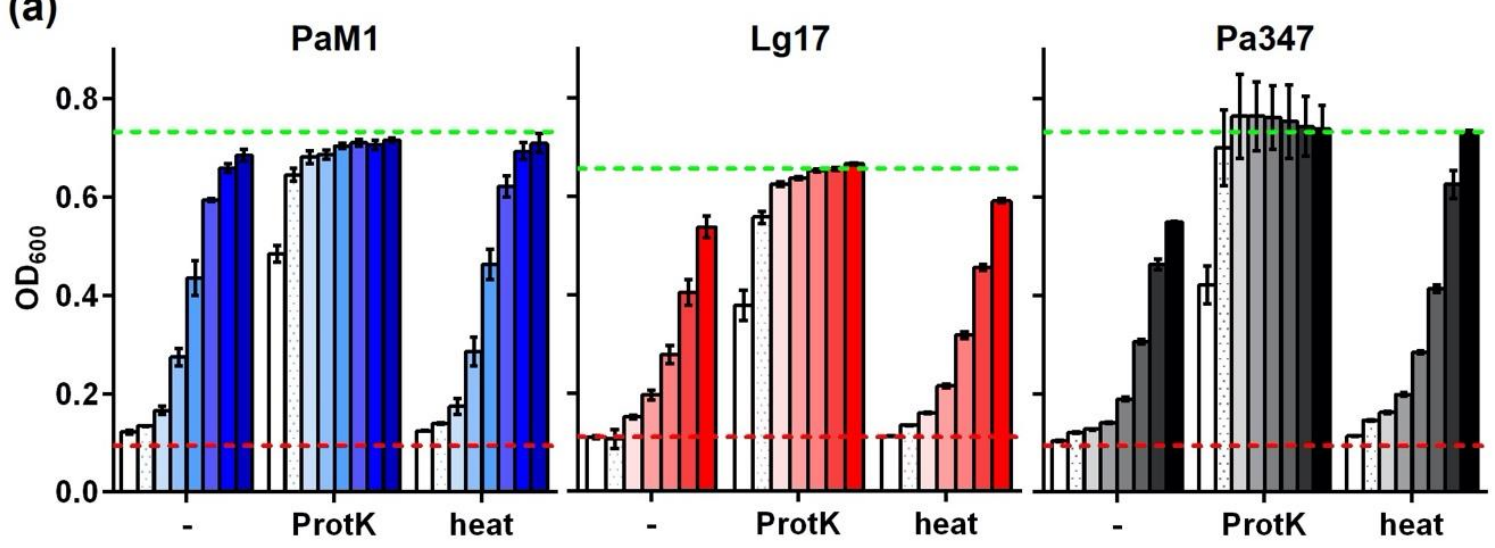

(b)

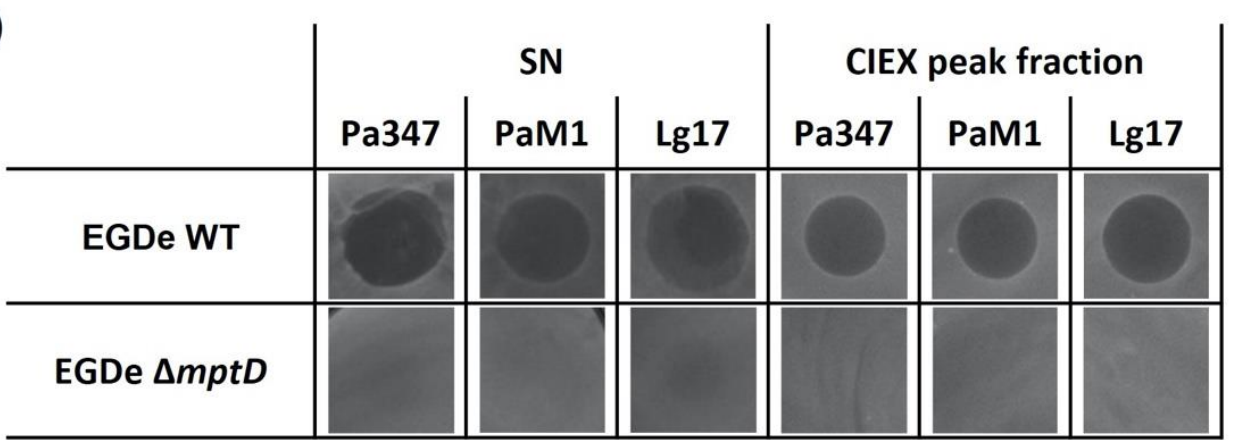

Figure 5. (a) Supernatants of P. acidilactici M1 (PaM1) and L. garvieae 17 (Lg17) or P. acidilactici 347 were treated for $3 \mathrm{~h}$ with proteinase $\mathrm{K}$ (ProtK) or incubated for $30 \mathrm{~min}$ at $80^{\circ} \mathrm{C}$ (heat) and activity was compared to the untreated control samples (-). Dilutions were 1:8-1:1024 and are indicated by a color scale with increasing intensity. Values are $\mathrm{OD}_{600}$ of the indicator strain and are mean \pm standard deviation (b) of $n=3$ experiments. The broken red and green lines indicate $\mathrm{OD}_{600}$ of the positive (i.e., complete inhibition of growth) or negative (i.e., sterile MRS medium) controls, respectively. (b) Spot-on-lawn assays to determine antimicrobial activity in cell-free culture supernatants (SN) or peak fractions collected during CIEX chromatography of ammonium sulfate-precipitated supernatant proteins (shown in Figure 4a) using either L. monocytogenes EGDe wildtype (EGDe WT) or its isogenic mutant EGY2 with an 84 bp deletion in the $m p t D$ gene (EGDe $\Delta m p t D)$.

\section{Discussion}

With the presented study, we aimed at establishing a set of methods for rapid identification of (novel) bacteriocin producers in a strain collection and the subsequent analysis of the compounds and its production. In a first step, a small collection of bacterial strains was isolated and typed to the species level using MALDI-Biotyping and 16S rRNA gene sequence analysis. Of the 55 isolates, all except two belonged to the genera Lactococcus, Enterococcus, Leuconostoc, Pediococcus, and Weissella. This is in line with those groups of LAB that are highly abundant in raw cow's milk detected by culture-dependent and independent methods [38] and can be cultivated on the MRS and GM17 agar used for isolation. Additionally, Corynebacterium spp. has been detected in cow's milk, albeit less frequently and in fewer numbers [38].

Typing based on 16S rRNA gene sequences is a more general approach and is considered as a reference method for microorganism identification [39]. Identification using $16 \mathrm{~S}$ rRNA gene sequences is performed by comparison to comprehensive sequences databases such as NCBI or EzBioCloud [40,41], but requires additional time for PCR amplification and DNA sequencing. In contrast, MALDI-Biotyping is a rapid and cost-effective alternative assay for bacterial identification [42] and is mostly used in the clinical identification of medically important microbial isolates $[43,44]$, but is also promoted for other applications $[45,46]$. The technique is based on generating mass spectral fingerprints of biomolecules contained in a sample and matching of this spectrum to spectra in a reference database $[43,44]$. Of the 
two methods used for typing, $16 \mathrm{~S}$ rRNA gene sequencing generally produces more robust results, suggesting that the commercially available databases of the MALDI-Biotyping system does not contain enough reference spectra of the bacterial groups isolated to cover the range of spectra within these groups. Similar observations have been made by several studies $[42,47,48]$.

Overall, our screening revealed that supernatants of about $50 \%$ of the isolates (total 27) significantly inhibited growth of $L$. monocytogenes. Of these supernatants, nine (i.e., $16 \%$, were also able to elicit membrane-damage. This is in the range of a similar screen that identified 28 bacteriocin producers in a collection of 138 strains isolated from dairy products using M17 and MRS media for isolation and L. innосиa as an indicator organism in an agar diffusion assay [49].

Results of the growth inhibition assay were more variable. Culture supernatants of lactic acid bacteria have a low $\mathrm{pH}$ and contain lactate and other short chain fatty acids. This combination has antimicrobial activity per se [50,51]. This suggests that at least some of the hits identified by the growth inhibition assay may not be bacteriocin producers but rather inhibit the growth of the sensor strain by a combination of SCFA and low $\mathrm{pH}$. Although the results were less variable in pHluorin assays, a number of supernatants also produced a partial or incomplete reduction in the fluorescence ratio of the sensor. This resembles the signals obtained with sublethal concentrations of pediocin and nisin in a previous study [31]. It remains to be investigated whether these intermediate signals are derived from a homogenous population of sensors with partial drop in intracellular $\mathrm{pH}$ in all bacteria, or a heterogenous population of sensors in which some bacteria have disrupted membranes and others are completely intact. For further screenings of larger libraries, the pHluorin assay definitely has advantages and yields a faster readout. On the other hand, it does not allow for the identification of bacteriostatic compounds that inhibit growth by mechanisms other than pore formation. Likewise, low concentrations of bacteriocins such as nisin, which have a dual mechanism with growth inhibition at low concentrations and pore formation at higher concentrations, will not be identified using the pHluorin assay. For screenings using growth dependent assays in 96 well format, the $\mathrm{pH}$ of the supernatants needs to be considered. This can either be addressed by neutralizing $\mathrm{pH}$ prior to the screen, which is laborious for a large number of supernatants, or by performing a secondary screen with neutralized supernatants only for a selection of hits.

Further investigation of the antimicrobial activity of isolates M1 and 17 revealed that the kinetics of production are similar to other bacteriocin producers with a maximum in the late exponential growth phase [52-54]. The antimicrobial compounds of isolates M1 and 17 were partially purified using ammonium sulfate precipitation and subsequent cation exchange chromatography of supernatant proteins, although the majority of the activity (approx. 90-95\%) was lost mostly during precipitation (Figure 4 and Table 1). A first set of experiments toward characterization of the antimicrobial compounds revealed that they are heat-stable and protease-sensitive, suggesting that they may be bacteriocins. P. acidilactici M1 and L. garvieae 17 belong to species, which are known to contain strains producing class II bacteriocins such as pediocins and garvicins [21,35,36]. Many class II bacteriocins target the IIC and IID subunits of a defined subgroup of PTSMan [55] and mutational analysis identified a number of amino acid residues in an extracellular domain of the IID subunits of L. lactis and L. garvieae strains that are critical for susceptibility [21,22]. Although L. monocytogenes EGDe encodes four members of the PTSMan family, a mutant (L. monocytogenes EGY2) has been described that carries a deletion of 84 bps in the mptD gene (lmo0098) encoding the IID subunit of PTS ${ }^{M a n}-2$ [37]. This mutant is highly resistant to the class II bacteriocin mesentericin Y105. The 84 bp deletion results in a protein that lacks amino acids 219-242 located in the C-terminal extracellular domain. Three amino acids that are critical for susceptibility of L. lactis and L. garvieae to class II bacteriocins are conserved in the wildtype MptD protein of L. monocytogenes EGDe. Two of the three amino acids (Y219 and G242) are located in the domain missing in the MptD protein of the mutant EGY2. We thus made use of the mutant EGY2 to test the antimicrobial compound present 
in supernatants of P. acidilactici M1 and L. garvieae 17. L. monocytogenes EGDe but not the mutant EGY2 was strongly inhibited by both supernatants and CIEX purified antimicrobial peptides of P. acidilactici M1 and L. garvieae 17 and the control strain P. acidilactici 347 known to produce pediocin PA-1 [56]. Indeed, this suggests that P. acidilactici M1 and L. garvieae 17 produce class II bacteriocins targeting the PTS ${ }^{\text {Man }}$.

\section{Materials and Methods}

\subsection{Strains and Culture Conditions}

Type strains and previously published strains of bacteria and their relevant characteristics used in this study are listed in Table 2. Listeria sp. strains were grown on BHI medium at $37^{\circ} \mathrm{C}$. Pediococcus acidilactici 347 was grown on MRS medium at $30^{\circ} \mathrm{C}$. Bacteria were routinely cultivated under aerobic conditions on an incubator shaker (I26R, Eppendorf, Hamburg, Germany; $150 \mathrm{rpm}$ ). For isolation of LAB, a sample of raw, unpasteurized milk of a cow was diluted and plated on GM17 and MRS agar and incubated at $30^{\circ} \mathrm{C}$. Single colonies were passaged three times on the respective medium to obtain pure cultures. Pure cultures were successfully obtained for nine strains isolated on MRS and 46 strains isolated on GM17 medium (i.e., a total of 55 isolates) (Supplementary Table S1).

Table 2. Bacterial strains used in this study.

\begin{tabular}{|c|c|c|}
\hline Strain & Relevant Characteristic & $\begin{array}{c}\text { Source/ } \\
\text { Reference }\end{array}$ \\
\hline \multicolumn{3}{|l|}{ Listeria monocytogenes } \\
\hline EGDe & Wildtype strain, serotype ${ }^{1 / 2}$ a type & [57] \\
\hline EGY2 & $\begin{array}{l}\text { EGDe derivative carrying a } \\
\text { deletion of } 84 \text { bp in the mptD gene } \\
\text { EGDe derivative harboring plasmid }\end{array}$ & [37] \\
\hline EGDe pNZ-P ${ }_{\text {help }}$-pHluorin & $\begin{array}{c}\text { pNZ-Phelp }- \text { pHluorin for constitutive } \\
\text { expression of pHluorin }\end{array}$ & {$[31]$} \\
\hline Pediococcus acidilactici 347 & $\begin{array}{l}\text { Natural producer of pediocin PA-1; isolated } \\
\text { from Spanish dry fermented sausages }\end{array}$ & [56] \\
\hline
\end{tabular}

For growth curve experiments, a $5 \mathrm{~mL}$ MRS pre-culture was inoculated with a single colony of respective isolates and incubated at $30^{\circ} \mathrm{C}$ and $150 \mathrm{rpm}$. Following o/N growth, pre-cultures were diluted to an $\mathrm{OD}_{600}$ of $0.2 \mathrm{in} 100 \mathrm{~mL}$ fresh MRS medium in a $250 \mathrm{~mL}$ Schott glass bottle and incubated at $30{ }^{\circ} \mathrm{C}$ and $100 \mathrm{rpm} . \mathrm{OD}_{600}$ and $\mathrm{pH}$ were measured at the indicated time-points during cultivation. At $\mathrm{t}=3,12,24$, and $48 \mathrm{~h}, 2 \mathrm{~mL}$ samples of culture broth were harvested and centrifuged at $11,000 \mathrm{rpm} \times g$ for $5 \mathrm{~min}$ to obtain the cell-free culture supernatant for subsequent assays.

\subsection{Identification of Raw Milk Isolates}

For taxonomic identification of the raw milk isolates, strains were grown on agar plates of the medium that was used for isolation and incubated overnight $(\mathrm{o} / \mathrm{N})$ at $30{ }^{\circ} \mathrm{C}$. A single colony was resuspended in $1 \mathrm{~mL}$ HPLC grade water and samples were analyzed by matrixassisted laser desorption ionization-time of flight mass spectrometry (MALDI-TOF MS) with a MALDI Biotyper Microflex system (Bruker Daltonics GmbH, Bremen, Germany), a well-established and widespread tool for the rapid identification of microbial isolates in clinical microbiology [58,59] An ethanol/formic acid sample preparation protocol was used as described elsewhere [60]. The spectrum obtained for each strain, representing largely the ribosomal proteins, was compared to three main Biotyper spectra (MSPs) libraries: an MBT compass library (revision F, version 9) containing 8468 MSPs, a filamentous fungi library (revision No. 1) containing 468 MSPs, and a SR library (revision No. 1) containing 104 MSPs, using the software associated with the Biotyper system according to the manufacturer's instructions. Identification scores of $\geq 2.3$ indicate a reliable identification to species and genus level, score values between 2.0 and 2.3 represent a probable identification to species 
level, score values between 1.7 and 2.0 represent a reliable genus level, and scores of $<1.7$ are regarded as unreliable.

For 16S rRNA gene sequencing, genomic DNA was prepared using the GeneEluteTM Bacterial Genomic DNA Kit (Sigma-Aldrich, Taufkirchen, Germany) according to the recommendations of the manufacturer with minor modifications. To increase yield, $5 \mathrm{~mL}$ of an o/N culture was used, and DNA was eluted in $50 \mu \mathrm{L}$ elution buffer. Genomic DNA was used as a template for amplification of $16 \mathrm{~S}$ rRNA genes using the Q $5^{\circledR}$ HighFidelity DNA Polymerase, universal primers 27f (AGAGTTTGATCCTGGCTCAG) and 1492r (GGTTACCTTGTTACGACTT) and standard PCR cycling conditions. PCR products were purified using the DNA Purification Kit (Macherey-Nagel, Düren, Germany) and sequenced by Sanger sequencing by a commercial service provider (Microsynth Seqlab $\mathrm{GmbH}$, Göttingen, Germany) using the same primers. The obtained sequences were combined to one sequence for the full length PCR product for each strain, analyzed using NCBI nucleotide BLAST [61], and the sequence hit in the database with the highest identity score was selected for the species identification of the isolate. As the control, P. acidilactici 347 was included in both typing approaches.

\subsection{Screening Procedures}

To identify isolates that release antimicrobial compounds, their spent culture supernatants were tested using two different methods in 96-well microtiter plates. To produce supernatants for screening assays, a single colony of each isolate grown o/ $\mathrm{N}$ on an agar plate was inoculated into $5 \mathrm{~mL}$ of MRS medium in a glass tube and cultures were incubated $\mathrm{o} / \mathrm{N}$ at $30^{\circ} \mathrm{C}$ and $150 \mathrm{rpm}$ on an incubator shaker (I26R, Eppendorf, Hamburg, Germany). Aliquots of $100 \mu \mathrm{L}$ of a preculture were then used to inoculate main cultures of $5 \mathrm{~mL}$ MRS, which were incubated in the same way for $16 \mathrm{~h}$. Supernatants were harvested by centrifugation $\left(4200 \times g, 4{ }^{\circ} \mathrm{C}, 15 \mathrm{~min}\right)$ and stored at $-20^{\circ} \mathrm{C}$ until further use.

Supernatants were screened using L. monocytogenes EGD-e/pNZ-P $\mathrm{P}_{\text {help }}$-pHluorin as an indicator strain. A single colony of the indicator was picked from a freshly grown agar plate, inoculated into $5 \mathrm{~mL}$ of BHI containing chloramphenicol $(12.5 \mu \mathrm{g} / \mathrm{mL})$ in a glass tube, and cultivated $\mathrm{o} / \mathrm{N}$ at $37^{\circ} \mathrm{C}$ with aeration (150 rpm).

To screen for growth inhibition, culture supernatants of the isolates or control strains were distributed in $50 \mu \mathrm{L}$ aliquots into individual wells of 96-well microtiter plates (Standard F; Sarstedt, Nümbrecht, Germany). Then, $150 \mu \mathrm{L}$ of fresh MRS medium was added (i.e., a 1:4 dilution), mixed, and $100 \mu \mathrm{L}$ was again removed. As controls, sterile MRS with (positive control) or without (negative control) $0.005 \%(w / v)$ CTAB were included on each plate of the screen. Where indicated, MRS containing pediocin PA-1 (Sigma-Aldrich, Taufkirchen, Germany) at a final concentration of $200 \mathrm{ng} / \mathrm{mL}$ was used. The o/N culture of the indicator strain was diluted (1:25) in fresh sterile BHI medium and $100 \mu \mathrm{L}$ of this suspension was added to each well of the 96-well screening plates. Plates were incubated at $37^{\circ} \mathrm{C}$ and $\mathrm{OD}_{600}$ was recorded after $7 \mathrm{~h}$.

Screening for membrane damage using the pHluorin assay was performed in a similar fashion as described previously [31]. The assay uses the $\mathrm{pH}$-dependent fluorescent protein pHluorin, which can be used to detect membrane damaging compounds by the change in intracellular $\mathrm{pH}_{\mathrm{i}}$ [31]. For the screening experiments, $100 \mu \mathrm{L}$ of supernatants of isolates and control strains as well as control media were distributed into black 96-well microtiter plates (ELISA plate black Med. Bind., F; Sarstedt, Nümbrecht, Germany). Bacteria of an o/N culture of L. monocytogenes EGD-e/pNZ-P $\mathrm{P}_{\text {help}}$-pHluorin were pelleted by centrifugation $\left(3000 \times g ; 10 \mathrm{~min}, 4^{\circ} \mathrm{C}\right)$, washed once in phosphate buffered saline, and resuspended in LMB buffer at $\mathrm{pH} 6.5$ [31] to an $\mathrm{OD}_{600}$ of 3. A total of $100 \mu \mathrm{L}$ of this suspension was added to each well of the 96-well screening plates. The microtiter plates were vortexed for $10 \mathrm{~s}$ on a Titramax 100 (Heidolph Instruments GmbH \& CO. KG, Schwabach, Germany) at $900 \mathrm{rpm}$, wrapped in aluminum foil, and incubated for $1 \mathrm{~h}$ at RT in the dark. Fluorescence was measured with excitation at 400 and $470 \mathrm{~nm}$ and emission at $510 \mathrm{~nm}$. The ratio of emission intensities after excitation at 400 and $470 \mathrm{~nm}$ were calculated. 


\subsection{Purification and Chromatography of Antimicrobial Compounds}

Potential bacteriocins of two isolates were partially purified by ammonium sulfate precipitation and subsequent cation exchange chromatography. For this purpose, $10 \mathrm{~mL}$ MRS pre-culture was inoculated with a single colony of respective isolates and incubated at $30{ }^{\circ} \mathrm{C}$ and $150 \mathrm{rpm}$. Following o/ $\mathrm{N}$ cultivation, the entire pre-culture was used to inoculate $500 \mathrm{~mL}$ MRS broth in a $11 \mathrm{Schott}$ glass bottle. These cultures were incubated for $18 \mathrm{~h}$ at $30^{\circ} \mathrm{C}$ and $100 \mathrm{rpm}$. Then, cell-free supernatants were prepared by centrifugation $(8000 \mathrm{rpm} \times g$, $4{ }^{\circ} \mathrm{C}, 45 \mathrm{~min}$ ) and supernatant proteins were precipitated by adding ammonium sulfate gradually at $4{ }^{\circ} \mathrm{C}$ with constant stirring to the supernatants until a saturation of $40 \%(w / v)$ ammonium sulfate was reached. The mixture was incubated o/N at $4{ }^{\circ} \mathrm{C}$ under constant stirring. Precipitated proteins were harvested by centrifugation $\left(8000 \mathrm{rpm} \times g, 4^{\circ} \mathrm{C}, 60 \mathrm{~min}\right)$ and the supernatant was discarded. The pellet containing precipitated peptides was dissolved in $50 \mathrm{~mL}$ HPLC-grade water and $\mathrm{pH}$ was adjusted to 3.9 to match the starting conditions of the cation exchange chromatography.

To further purify potential bacteriocins, cation exchange chromatography using a HiPrep SP FF 16/10 column (Cytiva, Freiburg, Germany; 20 mL volume capacity, 5 mL/min flow rate) was performed. The ÄKTA pure system (Cytiva, Freiburg, Germany) was employed for liquid chromatography. Before applying the sample, the column was equilibrated with five column volumes (CV) of equilibration buffer ( $20 \mathrm{mM}$ sodium dihydrogen phosphate, $\mathrm{pH}$ 3.9). Then, the sample was loaded onto the column and unbound material was removed by washing with $5 \mathrm{CV}$ wash buffer $(20 \mathrm{mM}$ phosphate buffer, $\mathrm{pH}$ 6.9). Subsequently, the potential bacteriocins were eluted stepwise with $3 \mathrm{CV}$ elution buffer ( $20 \mathrm{mM}$ phosphate buffer, $2 \mathrm{M}$ sodium chloride, $\mathrm{pH}$ 6.9). After each run, the column was extensively cleaned following the instructions of the manufacturer.

\subsection{Antimicrobial Activity Assays}

Bacteriocin activity in different samples was determined as described previously [62]. Briefly, two-fold serial dilutions of the supernatants and other samples were analyzed with the growth inhibition assay described above. One bacteriocin unit (BU) is defined as the reciprocal of the highest dilution showing at least $50 \%$ growth inhibition of the indicator strain. $\mathrm{BU} / \mathrm{mL}$ is then calculated using volumes of the samples in the assay and dilution factors. Where indicated, supernatants were incubated for $30 \mathrm{~min}$ at $80^{\circ} \mathrm{C}$ or treated with $0.5 \mathrm{mg} / \mathrm{mL}$ of proteinase $\mathrm{K}$ for $3 \mathrm{~h}$ at $37^{\circ} \mathrm{C}$. Proteinase $\mathrm{K}$ was inactivated by incubation for $15 \mathrm{~min}$ at $80^{\circ} \mathrm{C}$ prior to the experiments.

In some experiments, antimicrobial activity was analyzed using a spot-on-lawn assay. For this assay, $\mathrm{o} / \mathrm{N}$ cultures of sensor bacteria were diluted to an $\mathrm{OD}_{600}$ of 0.005 in hand-warm BHI agar. Agar containing sensor bacteria was poured into Petri dishes, and dried for $45 \mathrm{~min}$ under a clean bench. Then, $10 \mu \mathrm{L}$ of a sample (supernatant of producer strains or CEIX purified peptides) was spotted on these agar plates. Following incubation $\mathrm{o} / \mathrm{N}$ at $37^{\circ} \mathrm{C}$, agar plates were imaged using an iBright ${ }^{\mathrm{TM}}$ FL1000 Imaging System (Thermo Fisher, Langenselbold, Germany). Cell-free culture supernatants of producer strains were pasteurized $\left(15 \mathrm{~min}, 80^{\circ} \mathrm{C}\right)$ prior to the assay to avoid contamination with producer bacteria.

\subsection{Statistical Analysis}

Data of the screening experiments were analyzed by one-way ANOVA with Bonferroni post-test to calculate $p$-values adjusted for multiple. Values obtained with supernatants of the non-bacteriocin producer L. lactis MG1363 were set as the control condition. Differences between experimental groups (supernatants) were considered significant at $p$-values $<0$. Statistical analysis and visualization of data were performed using GraphPad Prism (version 6.07). 


\section{Conclusions}

In summary, our results present a set of tools for the screening of microbial collections for potential producers of antimicrobial activity and subsequent purification and characterization of the antimicrobial compounds. The pHluorin-based assay provides a simple and fast readout for compounds that disrupt membrane integrity, but bacteriocins with bacteriostatic activity are not detected. However, in combination with a second, growth-dependent screening discrimination between strains/compounds with bacteriostatic and bacteriolytic activity is possible. Both screening approaches are limited by the sensor bacteria and their sensitivity to different classes of bacteriocins but can be easily transferred to a wide range of (genetically accessible) microorganisms.

In our study, we focused on a rather small collection of bacteria isolated from raw milk and L. monocytogenes as the target/sensor organism but both screening approaches are transferrable to other sensor bacteria and larger collections from other sources (e.g., probiotic candidates in industrial collections). Moreover, we propose also considering classical starter or protective cultures as potential probiotics. Per recommendation of the FAO and WHO of the United Nations, probiotics are defined as "live microbial food supplements which when administered in adequate amounts confer a health benefit on the host" [63]. This includes any bacterium that elicits a positive effect on host health. In sort of a "three birds with one stone" scenario, our set of tools may allow for the identification of bacterial strains that combine characteristics of a starter culture with those of protective cultures and anti-infective probiotics.

Supplementary Materials: The following are available online at https:/ /www.mdpi.com/article/10.3 390/ijms22168615/s1.

Author Contributions: Conceptualization: O.G. and C.U.R.; Methodology: C.K.D., O.G., P.C., M.E., D.B.D. and C.U.R.; Validation: D.B.D., O.G. and C.U.R.; Formal analysis: C.K.D., S.S., K.V.O., J.S., S.J. and D.N.D.; Investigation: C.K.D., S.S., K.V.O., J.S., S.J. and D.N.D.; Resources: M.E., D.B.D. and C.U.R.; Data curation: C.U.R.; Writing—original draft preparation: S.S. and C.U.R.; Writing-review and editing: C.K.D., O.G., M.E., D.B.D. and C.U.R.; Visualization: C.U.R.; Supervision: P.C., M.E., D.B.D., O.G. and C.U.R.; Project administration: C.U.R.; Funding acquisition: C.U.R. All authors have read and agreed to the published version of the manuscript.

Funding: This study was partially funded by grants of the German Ministry for Education and Research to CUR within the ERA-IB2 consortium "SafeFood" (ID: ERA-IB-16- 014; Grant No. 031B0268) and the BMBF consortium "AMPLIFY (Grant No. 031B0826A). The funding bodies had no role in the design of the study, analysis of the data, or writing of the manuscript.

Institutional Review Board Statement: Not applicable.

Informed Consent Statement: Not applicable.

Data Availability Statement: All data presented in this study are available in the main body or supplementary files of the manuscript.

Acknowledgments: Not applicable.

Conflicts of Interest: The authors declare no conflict of interest.

\section{References}

1. Freitag, N.E.; Port, G.C.; Miner, M. Listeria monocytogenes-from saprophyte to intracellular pathogen. Nat. Rev. Genet. 2009, 7, 623-628. [CrossRef]

2. Carpentier, B.; Cerf, O. Review—Persistence of Listeria monocytogenes in food industry equipment and premises. Int. J. Food Microbiol. 2011, 145, 1-8. [CrossRef] [PubMed]

3. Gahan, C.G.M.; Hill, C. Listeria monocytogenes: Survival and adaptation in the gastrointestinal tract. Front. Cell. Infect. Microbiol. 2014, 4, 9. [CrossRef]

4. De Noordhout, C.M.; Devleesschauwer, B.; Angulo, F.J.; Verbeke, G.; Haagsma, J.; Kirk, M.; Havelaar, A.; Speybroeck, N. The global burden of listeriosis: A systematic review and meta-analysis. Lancet Infect. Dis. 2014, 14, 1073-1082. [CrossRef]

5. European Food Safety Authority; European Center for Disease Prevention and Control. The European Union summary report on trends and sources of zoonoses, zoonotic agents and food-borne outbreaks in 2015. EFSA J. 2016, 14, 14. [CrossRef] 
6. Mills, S.; Stanton, C.; Hill, C.; Ross, R. New Developments and Applications of Bacteriocins and Peptides in Foods. Annu. Rev. Food Sci. Technol. 2011, 2, 299-329. [CrossRef] [PubMed]

7. Cotter, P.D.; Hill, C.; Ross, R.P. Food microbiology: Bacteriocins: Developing innate immunity for food. Nat. Rev. Microbiol. 2005, 3, 777-788. [CrossRef] [PubMed]

8. Balciunas, E.M.; Martinez, F.C.; Todorov, S.; Franco, B.D.G.D.M.; Converti, A.; Oliveira, R.P.D.S. Novel biotechnological applications of bacteriocins: A review. Food Control. 2013, 32, 134-142. [CrossRef]

9. Sassone-Corsi, M.; Nuccio, S.-P.; Liu, H.; Hernandez, D.; Vu, C.T.; Takahashi, A.A.; Edwards, R.A.; Raffatellu, M. Microcins mediate competition among Enterobacteriaceae in the inflamed gut. Nat. Cell Biol. 2016, 540, 280-283. [CrossRef]

10. Kim, S.; Becattini, S.; Moody, T.U.; Shliaha, P.V.; Littmann, E.R.; Seok, R.; Gjonbalaj, M.; Eaton, V.; Fontana, E.; Amoretti, L.; et al. Microbiota-derived lantibiotic restores resistance against vancomycin-resistant Enterococcus. Nat. Cell Biol. 2019, 572, 665-669. [CrossRef]

11. Claesen, J.; Spagnolo, J.B.; Ramos, S.F.; Kurita, K.L.; Byrd, A.L.; Aksenov, A.A.; Melnik, A.V.; Wong, W.R.; Wang, S.; Hernandez, R.D.; et al. A Cutibacterium acnes antibiotic modulates human skin microbiota composition in hair follicles. Sci. Transl. Med. 2020, 12, eaay5445. [CrossRef] [PubMed]

12. Nakatsuji, T.; Chen, T.H.; Narala, S.; Chun, K.A.; Two, A.M.; Yun, T.; Shafiq, F.; Kotol, P.F.; Bouslimani, A.; Melnik, A.V.; et al. Antimicrobials from human skin commensal bacteria protect against Staphylococcus aureus and are deficient in atopic dermatitis. Sci. Transl. Med. 2017, 9, eaah4680. [CrossRef]

13. Corr, S.; Li, Y.; Riedel, C.U.; O’Toole, P.; Hill, C.; Gahan, C. Bacteriocin production as a mechanism for the antiinfective activity of Lactobacillus salivarius UCC118. Proc. Natl. Acad. Sci. USA 2007, 104, 7617-7621. [CrossRef] [PubMed]

14. Dobson, A.; Cotter, P.; Ross, R.; Hill, C. Bacteriocin Production: A Probiotic Trait? Appl. Environ. Microbiol. 2011, 78, 1-6. [CrossRef] [PubMed]

15. Papadimitriou, K.; Zoumpopoulou, G.; Foligne, B.; Alexandraki, V.; Kazou, M.; Pot, B.; Tsakalidou, E. Discovering probiotic microorganisms: In vitro, in vivo, genetic and omics approaches. Front. Microbiol. 2015, 6, 58. [CrossRef]

16. Cotter, P.D.; Ross, R.; Hill, C. Bacteriocins-A viable alternative to antibiotics? Nat. Rev. Genet. 2013, 11, 95-105. [CrossRef] [PubMed]

17. Chikindas, M.L.; Weeks, R.; Drider, D.; Chistyakov, V.; Dicks, L.M. Functions and emerging applications of bacteriocins. Curr. Opin. Biotechnol. 2018, 49, 23-28. [CrossRef] [PubMed]

18. Alvarez-Sieiro, P.; Montalbán-López, M.; Mu, D.; Kuipers, O.P. Bacteriocins of lactic acid bacteria: Extending the family. Appl. Microbiol. Biotechnol. 2016, 100, 2939-2951. [CrossRef]

19. Wiedemann, I.; Breukink, E.; van Kraaij, C.; Kuipers, O.P.; Bierbaum, G.; de Kruijff, B.; Sahl, H.-G. Specific Binding of Nisin to the Peptidoglycan Precursor Lipid II Combines Pore Formation and Inhibition of Cell Wall Biosynthesis for Potent Antibiotic Activity. J. Biol. Chem. 2001, 276, 1772-1779. [CrossRef]

20. Breukink, E.; De Kruijff, B. Lipid II as a target for antibiotics. Nat. Rev. Drug Discov. 2006, 5, 321-323. [CrossRef] [PubMed]

21. Tymoszewska, A.; Diep, D.B.; Aleksandrzak-Piekarczyk, T. The extracellular loop of Man-PTS subunit IID is responsible for the sensitivity of Lactococcus garvieae to garvicins A., B and C. Sci. Rep. 2018, 8, 15790. [CrossRef] [PubMed]

22. Tymoszewska, A.; Diep, D.B.; Wirtek, P.; Aleksandrzak-Piekarczyk, T. The Non-Lantibiotic Bacteriocin Garvicin Q Targets Man-PTS in a Broad Spectrum of Sensitive Bacterial Genera. Sci. Rep. 2017, 7, 1-14. [CrossRef]

23. Diep, D.B.; Skaugen, M.; Salehian, Z.; Holo, H.; Nes, I.F. Common mechanisms of target cell recognition and immunity for class II bacteriocins. Proc. Natl. Acad. Sci. USA 2007, 104, 2384-2389. [CrossRef] [PubMed]

24. Kjos, M.; Salehian, Z.; Nes, I.F.; Diep, D.B. An Extracellular Loop of the Mannose Phosphotransferase System Component IIC Is Responsible for Specific Targeting by Class IIa Bacteriocins. J. Bacteriol. 2010, 192, 5906-5913. [CrossRef] [PubMed]

25. Gabrielsen, C.; Brede, D.A.; Hernandez, P.E.; Nes, I.F.; Diep, D.B. The Maltose ABC Transporter in Lactococcus lactis Facilitates High-Level Sensitivity to the Circular Bacteriocin Garvicin ML. Antimicrob. Agents Chemother. 2012, 56, 2908-2915. [CrossRef] [PubMed]

26. Silva, C.; Silva, S.P.M.; Ribeiro, S.C. Application of Bacteriocins and Protective Cultures in Dairy Food Preservation. Front. Microbiol. 2018, 9, 594. [CrossRef]

27. Zou, J.; Jiang, H.; Cheng, H.; Fang, J.; Huang, G. Strategies for screening, purification and characterization of bacteriocins. Int. J. Biol. Macromol. 2018, 117, 781-789. [CrossRef]

28. Van Heel, A.J.; De Jong, A.; Song, C.; Viel, J.; Kok, J.; Kuipers, O.P. BAGEL4: A user-friendly web server to thoroughly mine RiPPs and bacteriocins. Nucleic Acids Res. 2018, 46, W278-W281. [CrossRef]

29. Blin, K.; Shaw, S.; Steinke, K.; Villebro, R.; Ziemert, N.; Lee, S.Y.; Medema, M.H.; Weber, T. antiSMASH 5.0: Updates to the secondary metabolite genome mining pipeline. Nucleic Acids Res. 2019, 47, W81-W87. [CrossRef] [PubMed]

30. Skinnider, M.A.; Johnston, C.W.; Gunabalasingam, M.; Merwin, N.J.; Kieliszek, A.M.; MacLellan, R.J.; Li, H.; Ranieri, M.R.M.; Webster, A.L.H.; Cao, M.P.T.; et al. Comprehensive prediction of secondary metabolite structure and biological activity from microbial genome sequences. Nat. Commun. 2020, 11, 1-9. [CrossRef]

31. Crauwels, P.; Schäfer, L.; Weixler, D.; Bar, N.S.; Diep, D.B.; Riedel, C.U.; Seibold, G.M. Intracellular pHluorin as Sensor for Easy Assessment of Bacteriocin-Induced Membrane-Damage in Listeria monocytogenes. Front. Microbiol. 2018, 9, 3038. [CrossRef] [PubMed] 
32. Miesenboeck, G.; De Angelis, D.A.; Rothman, J.E. Visualizing secretion and synaptic transmission with $\mathrm{pH}$-sensitive green fluorescent proteins. Nat. Cell Biol. 1998, 394, 192-195. [CrossRef]

33. Shabala, L.; Budde, B.; Ross, T.; Siegumfeldt, H.; McMeekin, T. Responses of Listeria monocytogenes to acid stress and glucose availability monitored by measurements of intracellular $\mathrm{pH}$ and viable counts. Int. J. Food Microbiol. 2002, 75, 89-97. [CrossRef]

34. Parte, A.C.; Carbasse, J.S.; Meier-Kolthoff, J.P.; Reimer, L.C.; Göker, M. List of Prokaryotic names with Standing in Nomenclature (LPSN) moves to the DSMZ. Int. J. Syst. Evol. Microbiol. 2020, 70, 5607-5612. [CrossRef]

35. Tosukhowong, A.; Zendo, T.; Visessanguan, W.; Roytrakul, S.; Pumpuang, L.; Jaresitthikunchai, J.; Sonomoto, K. Garvieacin Q, a Novel Class II Bacteriocin from Lactococcus garvieae BCC 43578. Appl. Environ. Microbiol. 2012, 78, 1619-1623. [CrossRef] [PubMed]

36. Porto, M.C.W.; Kuniyoshi, T.M.; Azevedo, P.O.D.S.D.; Vitolo, M.; Oliveira, R. Pediococcus spp.: An important genus of lactic acid bacteria and pediocin producers. Biotechnol. Adv. 2017, 35, 361-374. [CrossRef]

37. Dalet, K.; Cossart, P.; Cenatiempo, Y.; Héchard, Y. A o54-dependent PTS permease of the mannose family is responsible for sensitivity of Listeria monocytogenes to mesentericin Y105. Microbiology 2001, 147, 3263-3269. [CrossRef]

38. Quigley, L.; O'Sullivan, O.; Stanton, C.; Beresford, T.P.; Ross, R.; Fitzgerald, G.F.; Cotter, P.D. The complex microbiota of raw milk. FEMS Microbiol. Rev. 2013, 37, 664-698. [CrossRef] [PubMed]

39. Mellmann, A.; Cloud, J.; Maier, T.; Keckevoet, U.; Ramminger, I.; Iwen, P.; Dunn, J.; Hall, G.; Wilson, D.; LaSala, P.; et al. Evaluation of Matrix-Assisted Laser Desorption Ionization-Time-of-Flight Mass Spectrometry in Comparison to 16S rRNA Gene Sequencing for Species Identification of Nonfermenting Bacteria. J. Clin. Microbiol. 2008, 46, 1946-1954. [CrossRef]

40. Yoon, S.-H.; Ha, S.-M.; Kwon, S.; Lim, J.; Kim, Y.; Seo, H.; Chun, J. Introducing EzBioCloud: A taxonomically united database of 16S rRNA gene sequences and whole-genome assemblies. Int. J. Syst. Evol. Microbiol. 2017, 67, 1613-1617. [CrossRef] [PubMed]

41. Benson, D.A.; Cavanaugh, M.; Clark, K.; Karsch-Mizrachi, I.; Lipman, D.J.; Ostell, J.; Sayers, E.W. GenBank. Nucleic Acids Res. 2012, 41, D36-D42. [CrossRef]

42. Zhou, M.; Yang, Q.; Kudinha, T.; Zhang, L.; Xiao, M.; Kong, F.; Zhao, Y.; Xu, Y.-C. Using Matrix-Assisted Laser Desorption Ionization-Time of Flight (MALDI-TOF) Complemented with Selected 16S rRNA and gyrB Genes Sequencing to Practically Identify Clinical Important Viridans Group Streptococci (VGS). Front. Microbiol. 2016, 7, 1328. [CrossRef]

43. Patel, R. Matrix-Assisted Laser Desorption Ionization-Time of Flight Mass Spectrometry in Clinical Microbiology. Clin. Infect. Dis. 2013, 57, 564-572. [CrossRef]

44. Eigner, U.; Holfelder, M.; Oberdorfer, K.; Betz-Wild, U.; Bertsch, D.; Fahr, A.-M. Performance of a matrix-assisted laser desorption ionization-time-of-flight mass spectrometry system for the identification of bacterial isolates in the clinical routine laboratory. Clin. Lab. 2009, 55, 289-296. [PubMed]

45. Timperio, A.M.; Gorrasi, S.; Zolla, L.; Fenice, M. Evaluation of MALDI-TOF mass spectrometry and MALDI BioTyper in comparison to $16 \mathrm{~S}$ rDNA sequencing for the identification of bacteria isolated from Arctic sea water. PLoS ONE 2017, 12, e0181860. [CrossRef] [PubMed]

46. Pomastowski, P.; Złoch, M.; Rodzik, A.; Ligor, M.; Kostrzewa, M.; Buszewski, B. Analysis of bacteria associated with honeys of different geographical and botanical origin using two different identification approaches: MALDI-TOF MS and 16S rDNA PCR technique. PLoS ONE 2019, 14, e0217078. [CrossRef]

47. Carrasco, G.; Caballero, J.D.D.; Garrido, N.; Valdezate, S.; Cantón, R.; Sáez-Nieto, J.A. Shortcomings of the Commercial MALDITOF MS Database and Use of MLSA as an Arbiter in the Identification of Nocardia Species. Front. Microbiol. 2016, 7, 542. [CrossRef]

48. Kopcakova, A.; Stramova, Z.; Kvasnova, S.; Godany, A.; Perhacova, Z.; Pristas, P. Need for database extension for reliable identification of bacteria from extreme environments using MALDI TOF mass spectrometry. Chem. Pap. 2014, 68, 1435-1442 [CrossRef]

49. Yang, E.; Fan, L.; Jiang, Y.; Doucette, C.; Fillmore, S. Antimicrobial activity of bacteriocin-producing lactic acid bacteria isolated from cheeses and yogurts. AMB Express 2012, 2, 48. [CrossRef]

50. Russell, J.B.; Diez-Gonzalez, F. The Effects of Fermentation Acids on Bacterial Growth. Adv. Microb. Physiol. 1997, 39, 205-234. [CrossRef]

51. Shelef, L.A. Antimicrobial Effects of Lactates: A Review. J. Food Prot. 1994, 57, 445-450. [CrossRef]

52. Makhloufi, K.M.; Carré-Mlouka, A.; Peduzzi, J.; Lombard, C.; Van Reenen, C.A.; Dicks, L.; Rebuffat, S. Characterization of Leucocin B-KM432Bz from Leuconostoc pseudomesenteroides Isolated from Boza, and Comparison of its Efficiency to Pediocin PA-1. PLoS ONE 2013, 8, e70484. [CrossRef]

53. Anastasiadou, S.; Papagianni, M.; Filiousis, G.; Ambrosiadis, I.; Koidis, P. Pediocin SA-1, an antimicrobial peptide from Pediococcus acidilactici NRRL B5627: Production conditions, purification and characterization. Bioresour. Technol. 2008, 99, 5384-5390. [CrossRef]

54. Telke, A.A.; Ovchinnikov, K.V.; Vuoristo, K.; Mathiesen, G.; Thorstensen, T.; Diep, D.B. Over 2000-Fold Increased Production of the Leaderless Bacteriocin Garvicin KS by Increasing Gene Dose and Optimization of Culture Conditions. Front. Microbiol. 2019, 10, 389. [CrossRef]

55. Kjos, M.; Nes, I.F.; Diep, D.B. Class II one-peptide bacteriocins target a phylogenetically defined subgroup of mannose phosphotransferase systems on sensitive cells. Microbiology 2009, 155, 2949-2961. [CrossRef] 
56. Rodríguez, J.; Cintas, L.; Casaus, P.; Martínez, M.; Suárez, A.; Hernandez, P.E. Detection of pediocin PA-1-producing pediococci by rapid molecular biology techniques. Food Microbiol. 1997, 14, 363-371. [CrossRef]

57. NBSP; Glaser, P.; Frangeul, L.; Buchrieser, C.; Rusniok, C.; Amend, A.; Baquero, F.; Berche, P.; Bloecker, H.; Brandt, P.; et al. Comparative genomics of Listeria species. Science 2001, 294, 849-852. [CrossRef]

58. Kostrzewa, M. Application of the MALDI Biotyper to clinical microbiology: Progress and potential. Expert Rev. Proteom. 2018, 15, 193-202. [CrossRef]

59. Sauget, M.; Valot, B.; Bertrand, X.; Hocquet, D. Can MALDI-TOF Mass Spectrometry Reasonably Type Bacteria? Trends Microbiol. 2017, 25, 447-455. [CrossRef] [PubMed]

60. Wang, J.; Wang, H.; Cai, K.; Yu, P.; Liu, Y.; Zhao, G.; Chen, R.; Xu, R.; Yu, M. Evaluation of three sample preparation methods for the identification of clinical strains by using two MALDI-TOF MS systems. J. Mass Spectrom. 2021, 56, e4696. [CrossRef] [PubMed]

61. Altschul, S.F.; Madden, T.L.; Schäffer, A.A.; Zhang, J.; Zhang, Z.; Miller, W.; Lipman, D.J. Gapped BLAST and PSI-BLAST: A new generation of protein database search programs. Nucleic Acids Res. 1997, 25, 3389-3402. [CrossRef] [PubMed]

62. Holo, H.; Nilssen, O.; Nes, I.F. Lactococcin A, a new bacteriocin from Lactococcus lactis subsp. cremoris: Isolation and characterization of the protein and its gene. J. Bacteriol. 1991, 173, 3879-3887. [CrossRef] [PubMed]

63. FAO; WHO. Working Group Report on Drafting Guidelines for the Evaluation of Probiotics in Food; World Health Organization: London, ON, Canada, 2002. 